Short communication

\title{
Differential Haematobia irritans infestation levels in beef cattle raised in silvopastoral and conventional pasture systems
}

\author{
Márcia Cristina de S. Oliveira ${ }^{a}$, Maria Luiza F. Nicodemo ${ }^{a}$, Marcos R. Gusmão ${ }^{a}$, \\ José Ricardo M. Pezzopane ${ }^{\mathrm{a}}$, Talita B. Bilhassi ${ }^{\mathrm{b}}$, Clarissa H. Santana ${ }^{\mathrm{b}}$, Thuane C. Gonçalves ${ }^{\mathrm{b}}$, \\ Márcio D. Rabelo ${ }^{\mathrm{a}}$, Rodrigo Giglioti ${ }^{\mathrm{b}, *}$ \\ a Embrapa Pecuária Sudeste, Rodovia Washington Luiz, km 234, São Carlos, SP, Brazil \\ b Universidade Estadual Paulista "Júlio de Mesquita Filho Departamento de Zootecnia, Jaboticabal, SP, Brazil
}

\section{A R T I C L E I N F O}

\section{Keywords:}

Horn fly

Beef cattle

Biodiversity

Environmental complexity

\begin{abstract}
A B S T R A C T
The use of silvopastoral systems (SPS) can be a good alternative to reduce the environmental impacts of livestock breeding in Brazil. One of the reasons for its scarce adoption is the lack of information on health and productivity of cattle raised under these conditions. The experiment reported here was designed to compare the infestation by external parasites - the cattle tick (Rhipicephalus microplus), horn fly (Haematobia irritans), and larvae of the botfly (Dermatobia hominis) - in beef cattle raised in a SPS and a conventional pasture system (CPS), evaluated for 24 months. Data on air and soil temperature, solar radiation, wind incidence and water balance were used to characterize the SPS and CPS. $R$. microplus adult females and D. hominis larvae were counted on the body of each animal to determine the parasites burdens, but we did not find significant differences between the two systems. Horn flies counts on animals' body, and analysis of the horn fly and its pupal parasitoids associated with the dung pats were obtained in the two systems. Horn fly infestation was significantly lower $(p=0.01)$ in the SPS $(13.17 \pm 3.46)$ in comparison with the CPS $(24.02 \pm 4.43)$. In SPS and CPS, respectively, the mean densities of pupae of $H$. irritansin dung pats were 9.8 and 10.7; the mean density of adults of $H$. irritans, 3.7 and 3.5; and the density of its pupal parasitoids were 20.5 and 5.4. The effect of production system was significant $(p<0.05)$ only for the occurrence of pupal parasitoids of the horn fly, where the greatest occurrences of these natural enemies were in the SPS. These data indicate that natural enemies were able to control, at least partially, the horn fly populations in the cattle.
\end{abstract}

\section{Introduction}

The use of silvopastoral systems (SPS), which combine pastures for cattle grazing and trees, can reduce the negative impact of livestock breeding on the environment. SPS has the potential to enhance soil fertility and biodiversity, reduce erosion, improve water quality, sequester carbon (Jose, 2009), and improve microclimate (Leme et al., 2005; Souza et al., 2007), minimize pests and diseases (Inomoto et al., 2007; Gorgen et al., 2008). Tropical climates favor the development of various ectoparasites that affect cattle, especially the tick Rhipicephalus microplus, larvae of the botfly Dermatobia hominisand the horn fly Haematobia irritans. However, few studies have been published on these parasites in SPS, and the studies available have not directly assessed the causality between different abiotic factors - especially microclimate variables that influence the relations that occur in the natural environment and the free stages of parasites. Furthermore, contradictory results have been reported in studies of cattle ectoparasites, due to the complexity of the interactions. For example, while Giraldo et al. (2011), in Colombia, described a significant reduction in the levels of infestation by horn flies on cattle raised in an SPS in comparison with a CPS, Silva et al. (2013), in Brazil, did not find significant differences between the average infestation by ticks and horn flies on cattle raised in an SPS with eucalyptus compared to a CPS. The objectives of this study were to evaluate the infestation levels of the ectoparasites in beef cattle raised in an SPS compared to CPS, and to assess variations in microclimate and quantity of the horn fly and its parasitoids associated with the dung pats in the two systems. Results with regard to gastrointestinal nematodes and animal performances were previously published (Oliveira et al., 2016).

\footnotetext{
* Corresponding author at: Embrapa Pecuária Sudeste, Rodovia Washington Luiz, Km 234, CP 339, 13560-970, São Carlos, SP, Brazil.

E-mail address: gigliotirodrigo@gmail.com (R. Giglioti).
} 


\section{Material and methods}

\subsection{Characterization of the systems}

The study was conducted in São Carlos, SP, Brazil (2201'10" South latitude, $47^{\circ} 53^{\prime} 38^{\prime \prime}$ West longitude). The climate is classified as CwaAwa (Köppen), dry between April and September and rainy between October and March. The average yearly temperature is $21.2{ }^{\circ} \mathrm{C}$, and the average annual relative humidity is $75.6 \%$. The terrain has slopes of 3 $\%$ to $5 \%$ and an average altitude of $860 \mathrm{~m}$. The SPS was established in December 2007, in an area formed by Urochloa decumbens (syn. Brachiaria decumbens) on dark red latosol (EMBRAPA, 2006) with medium texture. Two areas measuring $275 \mathrm{~m} \times 140 \mathrm{~m}$ were divided into six paddocks $(0.41 \mathrm{ha})$ in each one. The indigenous tree species were planted directly in the pasture (Anadenanthera colubrina, Peltophorum dubium, Zeyheria tuberculosa, Cariniana estrellensis, Piptadenia gonoacantha, Guazuma ulmifolia and Croton floribundus), in three rows, accompanying the terrain, at a spacing of $2.5 \mathrm{~m} \times 2.5 \mathrm{~m} \times 17 \mathrm{~m}$, resulting in about 600 trees/ha. Each row of trees occupies seven meters and is set off from the pasture with an electric fence at a distance of one meter. Similarly, conventional pasture system (CPS) area was composed of six paddocks of Urochloa decumbens, each with 0.5 ha, with two repetitions (Fig. 1).

The experimental group consisted of 32 male Canchim cattle (5/8 Charolais/zebu, 16 in each system), weaned at eight months of age. They were vaccinated against foot and mouth disease and treated with a commercial acaricide containing cypermethrin (15\%), chlorpyrifos (25\%) and citronellal (1\%), 1 1/800 1 of water, $5 \mathrm{l} /$ animal and an anthelmintic (albendazole sulfoxide $10 \%, 1 \mathrm{ml} / 40 \mathrm{~kg}$ body weight) before being placed in the paddocks. The animals received mineral supplementation during the rainy season, a protein-supplemented mixture $(50 \%$ protein, $100 \mathrm{~g} / \mathrm{Kg}$ body weight/day) during the dry season and were submitted to rotational grazing according to Euclides and Euclides Filho (1998). At the end of each grazing cycle (42 days), the animals were taken to a corral to count the flies. All the animals (SPS and CPS) were submitted to tick control, in which they were treated with cypermethrin as described previously, according to animal welfare requests. These treatments were done in the entire herd on seven occasions (August, October and December 2013; May, July, November and December 2014), when the number of adult female ticks in at least one animal was greater than 50 .

\subsection{Meteorological parameters}

The microclimate in each system was characterized by the data on air and soil temperature, overall solar radiation $\left(\mathrm{MJ} \mathrm{m}^{-2} \mathrm{day}^{-1}\right)$ and wind incidence $\left(\mathrm{m} \mathrm{s}^{-1}\right)$. The data were measured continually at four points between the two rows of trees in the SPS and at one point in the CPS and were used to calculate monthly means. Each week the soil moisture was measured with a collection module and capacitance sensor (Diviner ${ }^{\circ}$ ). In the CPS, data were obtained at four pasture points at random, while in the SPS the access tubes to measure moisture were installed at four points between the two rows of trees. The values were the means of the four measurements in both cases.

\subsection{Ectoparasites study}

The experimental period lasted from August 1, 2013, to July 16, 2015, during which parasites were counted 18 times, at the end of each grazing cycle ( 42 days). The horn flies were counted by digital photographs of the dorsal region of each animal (Fraga et al., 2005).The images were visualized on the computer monitor using the Microsoft Paint program to facilitate counting $R$. microplusadult femalesand $D$. hominislarvae were counted on the body of each animal to determine the parasites burdens, but we did not find significant differences between the two systems(data not shown). The experimental protocols were approved by the committee on the ethical use of animals for experimentation of Embrapa Pecuária Sudeste (PRT no. 04/2013).

\subsection{Analysis of the horn fly and its pupal parasitoids associated with the dung pats}

To evaluate the $H$. irritans and its parasitoids, at the end of the occupation period of each paddock ten dung pats were selected in four paddocks of each system (SPS and CPS). After exposure for seven days, the pats were collected together with the underlying soil layer to a depth of $5 \mathrm{~cm}$. The material was taken to the laboratory for separation of the horn fly pupae by the flotation method (Tobin and Pitts, 1999). The pupae were placed individually in microtubes with a volume of $1.5 \mathrm{ml}$ and were kept in a BOD incubator $\left(25 \pm 5{ }^{\circ} \mathrm{C}, 65 \% \mathrm{RH}\right)$ until the emergence of the flies or its pupal parasitoids. These evaluations were carried out in the winter, spring and summer of 2013, autumn, winter, spring and summer of 2014 and the autumn and winter of 2015. The parasitoid specimens were identified by genus, the adult flies at the level of species for $H$. irritans and family for other Diptera.

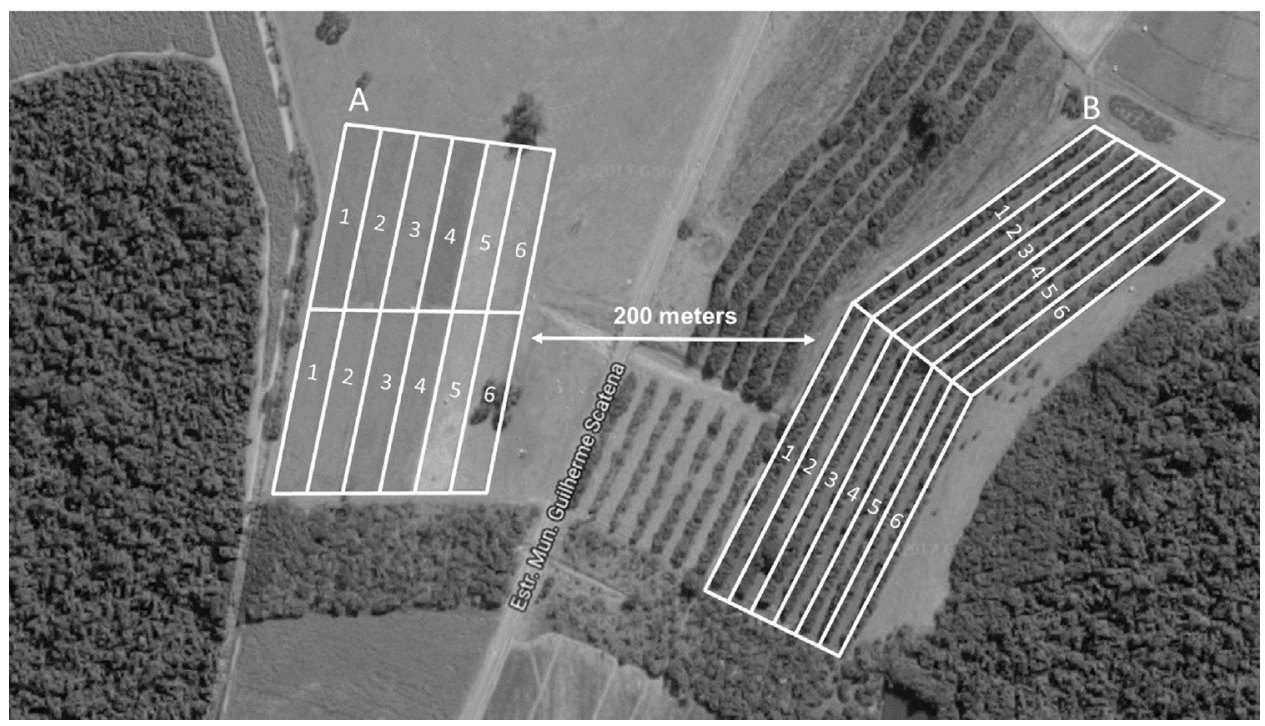

Fig. 1. Representative sketch of the location of the experimental site: the conventional pasture system (A) and the silvopastoral system (B) (Embrapa experimental farm, São Carlos- SP, Brazil). 


\subsection{Statistical analysis of the data}

The data from horn fly counts were normalized by $\log 10(n+1)$ transformation and submitted to repeated measurements analysis under the MIXED procedure. The effects tested in this model were the breeding system (BS $=$ CPS or SPS), collection date (CO, month/year) and interactions. The repeated statement was used to account for covariance in the measures taken from the same animal on the different collection dates. A compound symmetry structure was used to form the covariance matrix. In turn, the climate data and the data on insects associated with the dung pats, densities of horn fly (pupae and adults) and its parasitoids were analyzed using the GLM procedure considering the effects of the production system (SPS or CPS) and season of evaluation. A 5\% level of significance was used throughout, and all analyses were carried out using SAS statistical package (SAS, 2002).

\section{Results}

\subsection{Climatic factors}

The mean solar radiation values, followed by the standard deviations, were $10.83 \pm 0.17$ and $17.35 \pm 0.17 \mathrm{MJ} \mathrm{m}^{-2}$ day $^{-1}$ for the SPS and CPS, respectively (Fig. 2A). The solar radiation was lower in the SPS in all the evaluations $(p<0.05)$, with the greatest attenuations observed in April 2014 and March 2015, with values higher than $50 \%$, probably due to the solar declination and greater leaf growth by the trees in this period. Significant differences $(p<0.05)$ were also observed for average wind speed in the two systems (Fig. 2B), with means of $1.36 \pm 0.02 \mathrm{~m} / \mathrm{s}$ for the CPS and $0.64 \pm 0.02 \mathrm{~m} / \mathrm{s}$ for the SPS, and reductions of $34.8 \%$ to $65.1 \%$ in the SPS in relation to the CPS. Soil and air average temperatures also differed significantly $(p<0.05)$ between the systems, with values of $22.47 \pm 0.05{ }^{\circ} \mathrm{C}$ (CPS) versus $22.22 \pm 0.05{ }^{\circ} \mathrm{C} \quad$ (SPS) and $21.42 \pm 0.07{ }^{\circ} \mathrm{C}$ (CPS) versus $21.19 \pm 0.07{ }^{\circ} \mathrm{C}$ (SPS), respectively. The quantities of water stored in the topmost soil layer $(0-10 \mathrm{~cm})$ in the pastures of the two experimental areas did not differ significantly $(0.21 \pm 0.03 \mathrm{~mm})$. Only below the trees in the SPS, the average quantity of water was lower $(0.20 \pm 0.04$ $\mathrm{mm})$.

\subsection{H. irritans counts}

With respect to the number of horn flies on the animals, there were significant effects $(p \leq 0.01)$ of the system, collection date and interaction of system and collection date. Lower averages $(p=0.01)$ were observed in the SPS $(13.17 \pm 3.46)$ in comparison with the CPS (24.02 \pm 4.43) although only in October and December 2013 and November 2014 and June 2015 there were significant differences

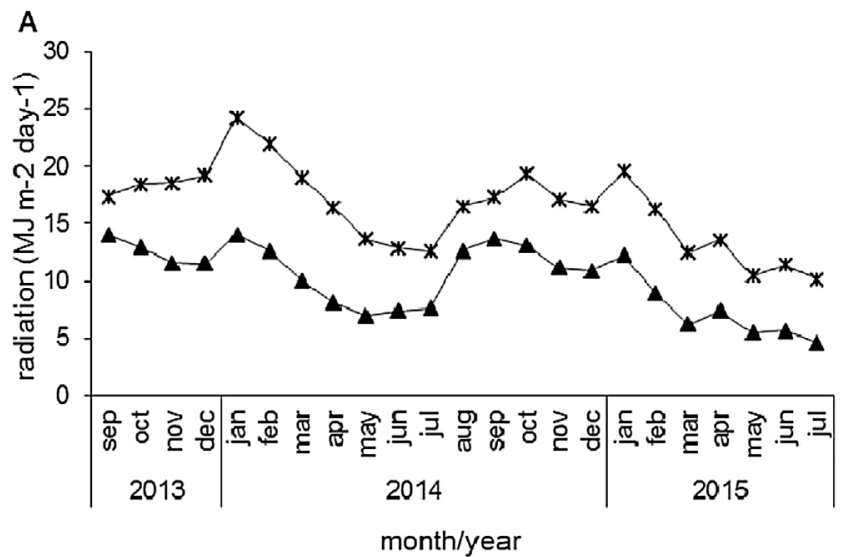

between the two systems (Fig. 3).

\subsection{Horn fly and its parasitoids associated with the dung pats}

Six Diptera morphospecies were identified in the dung pats: three morphospecies of Muscidae, with the identification of individuals of the species $H$. irritans, two morphospecies of Sarcophagidae and one morphospecies of Fanniidae. Two morphospecies of hymenopterous parasitoids of the families Braconidae and Pteromalidae were found parasitizing horn fly pupae, with the morphospecies identified as Aphaereta spp. and Spalangia spp.

The mean densities of $H$. irritans (pupae and adults) and its pupal parasitoids in the SPS and CPS were summarized in Table 1 . The effect of production system was significant $(p=0.01)$ only for the occurrence of pupal parasitoids of the horn fly, where the greatest occurrences of these natural enemies were in the SPS. No significant effect $(p>0.05)$ was noted on the density of insects, considering the interaction between season and production system.

\section{Discussion}

The relationship between ectoparasites and the host depends on multiple factors: characteristics of the environment (temperature, radiation, humidity, and vegetation), host aspects (age, genetically determined resistance, immune response, and nutritional status) and the presence of natural enemies of the ectoparasites. This makes it hard to isolate, under field conditions, the most important factors contributing to the result observed. In this study, it was necessary to use cypermethrin treatments to control the tick population on the animals. As this treatment is effective against several arthropods, to avoid differences between systems caused by its use, when female tick counts were 50 or higher in at least one animal, the entire herd was treated, simultaneously, regardless of the type of system. Ectoparasites are more vulnerable to predators and adverse environmental conditions during the life stages off the host (Martinez and Merino, 2011). Low air humidity and soil moisture, high temperature, strong wind and high insolation have been implicated in greater potential for desiccation of eggs and larvae, as well as for higher energy expenditure by the parasite (Furlong, 2005).

The differing plant cover altered the microclimate (Fig. 2) and might have formed niches favorable to the multiplication, survival and infestation ability of the parasites. More diverse plant cover implies in greater potential availability of resources during the year, consequently favoring a wider variety of organisms. The greater structural complexity of this system favors biodiversity, which as a rule is a fundamental feature reducing parasitism (Grønvold et al., 1996; Civitello et al., 2015). We observed lower infestation by horn flies on the cattle

B

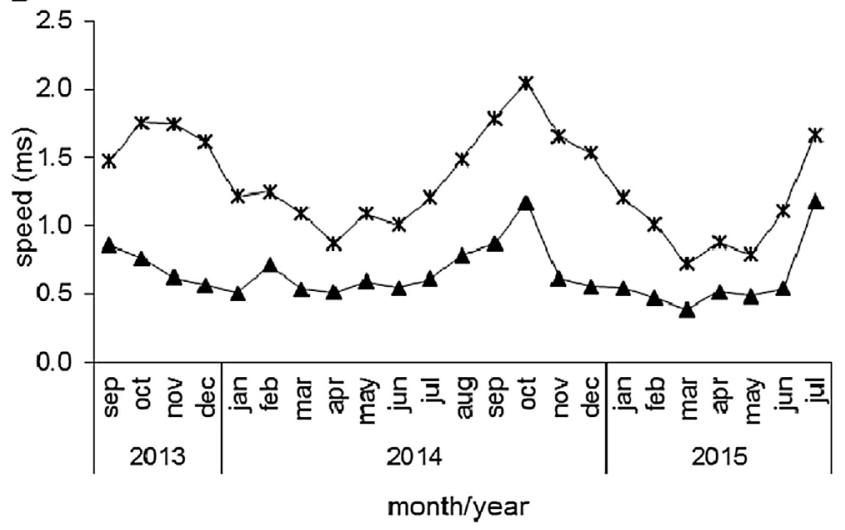

Fig. 2. Solar radiation (A) and Wind speed (B) in the in the conventional pasture system (CPS) and silvopastoral system (SPS) during the experimental period. 


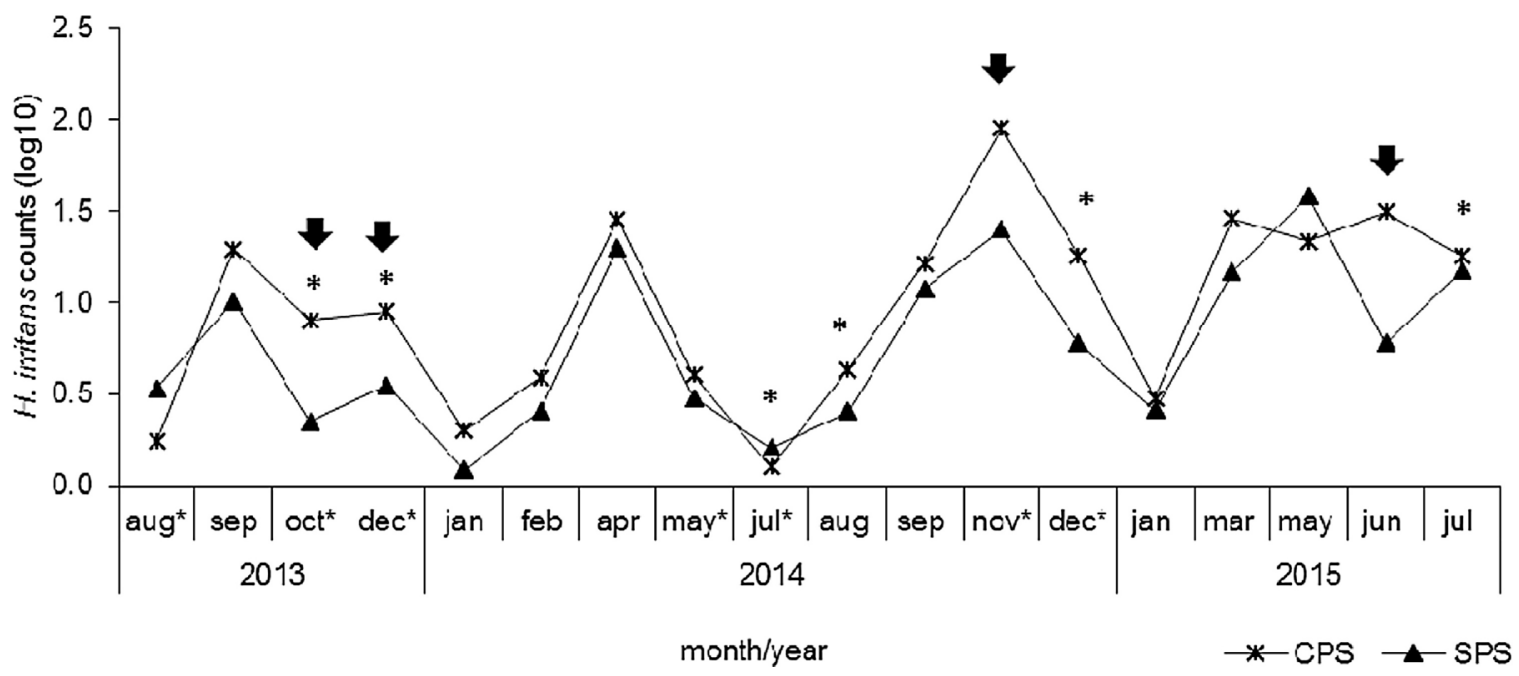

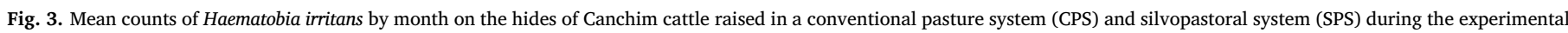
period. $\boldsymbol{V}=$ = the months with significantly differences betwen the two systems; * = the months with treatment with acaricide.

Table 1

Mean (insects/ten dung pats) of horn fly and its parasitoids evaluated on the silvopastoral (SPS) and conventional pasture systems (CPS) from winter of 2013 to winter of 2015.

\begin{tabular}{lllllll}
\hline \multirow{2}{*}{$\begin{array}{l}\text { Pasture } \\
\text { systems }\end{array}$} & Horn fly & & & \multicolumn{2}{l}{ Parasitoids of horn fly } \\
\cline { 2 - 3 } \cline { 5 - 6 } \cline { 5 - 6 } & pupae & adult & & Aphaereta sp. & Spalangia sp. & $\begin{array}{l}\text { Total of } \\
\text { Parasitoids }\end{array}$ \\
\hline SPS & $9.83 \mathrm{a}^{1}$ & $3.67 \mathrm{a}$ & & $15.61 \mathrm{a}$ & $4.92 \mathrm{a}$ & $20.53 \mathrm{a}$ \\
CPS & $10.86 \mathrm{a}$ & $3.53 \mathrm{a}$ & $4.67 \mathrm{~b}$ & $0.75 \mathrm{~b}$ & $5.42 \mathrm{~b}$ \\
\hline
\end{tabular}

1 The averages followed by different letters in the column differ from each other at the significance level of $\mathrm{p}<0.05$.

raised in the SPS $(p<0.05)$, in accordance with Giraldo et al. (2011). They attributed lower infestations by $H$. irritans on animals raised in SPS to the presence of various predators of the larvae of these flies in cattle dung. Soca et al. (2002) reported greater degradation of dung pats in a silvopastoral system compared to open pasture (90\% vs. 40 $\%$ ), associating this with the greater richness of edaphic fauna, especially coprophagous beetles, which destroy and bury the fecal material, exposing the eggs and larvae of parasites to other predators and increasing the risks of desiccation.

The presence of different organisms that use excrement for shelter, reproduction, and feeding, or that establish interactions of competition, parasitism, and predation with other organisms also influences the survival of the free-living stage of cattle parasites in pastures (Bianchin and Catto, 2008). In this experiment, the occurrence of fly pupae and adults was similar in the two systems, but the numbers of pupal parasitoids were higher in the SPS. These data indicate that natural enemies were able to control at least partially (not tested), the horn fly populations in the pastures. Honer et al. (1993) reported that natural enemies like predators and parasitoids can limit the reproduction of $H$. irritans in feces by around $90 \%$, by attacking larvae and pupae. The adult stages of horn flies are less dependent on climate conditions, so the critical times to control these pests are during the stages of their development in dung (eggs, larvae and pupae).

In conclusion: environmental alterations caused by the presence of trees, notably the reduction of solar radiation and wind speeds and increased abundance and richness of the fauna associated with the pastures, can affect ectoparasites dynamics on cattle raised in the SPS. The cattle infestations by horn flies were significantly lower in the SPS.

\section{References}

Bianchin, I., Catto, J.B., 2008. Epidemiologia e alternativas de controle de helmintos em bovinos de corte na Região Central do Brasil. (Accessed 06 Octobre 2016). http:// helminto.inta.gob.ar/Congreso\%20Brasil\%202008/EPIDEMIOLOGIA\%20E \%20ALTERNATIVAS\%20DE\%20CONTROLE\%20DE\%20HELMINTOS\%20EM \%20BOVINOS\%20DE\%20CORTE\%20NA\%20REGI\%C3\%830\%20CENTRAL\%20DO \%20BRASIL.pdf.

Civitello, D.J., Cohen, J., Fatima, H., Halstead, N.T., Liriano, J., McMahon, T.A., Ortega, C.N., Sauer, E.L., Sehgal, T., Young, S., Rohr, J., 2015. Biodiversity inhibits parasites: broad evidence for the dilution effect. Proc. Natl. Acad. Sci. U. S. A. 112, 8667-8671.

EMBRAPA Empresa Brasileira de Pesquisa Agropecuária, Centro Nacional de Pesquisas de Solos CNPS, 2006. System brasileiro de classificação de Solos. EMBRAPA Solos, Rio de Janeiro.

Euclides, V.P.B., Euclides Filho, K., 1998. Uso de animais na avaliação de forrageiras. Embrapa-CNPGC. Campo Grande (Embrapa-CNPGC. Documentos, 74). http://www. infoteca.cnptia.embrapa.br/infoteca/handle/doc/318251.

Fraga, A.B., Alencar, M.M., Figueiredo, L.A., 2005. Genetics analysis of the infestation of females of Caracu cattle breed by Horn Fly (Haematobia irritans) (L) (diptera, Muscidae), Gen. Mol. Biol. 28 (2), 242-247.

Furlong, J., 2005. Carrapato: problemas e soluções. Embrapa Gado de Leite, Juiz de Fora.

Giraldo, C., Escobar, F., Chara, J.D., Calle, Z., 2011. The adoption of silvopastoral systems promotes the recovery of ecological processes regulated by dung beetles in the Colombian Andes. Insect Conserv. Divers. 4, 115-122.

Gorgen, C.A., Civardi, E., Perreto, E., Carneiro, L.C., Silveira Neto, A.N., Ragagnin, V., Lobo Junior, M., 2008. Controle de Sclerotinia sclerotiorum com o manejo de Brachiaria ruziziensis e aplicação de Trichoderma harzianum. Embrapa Cerrados: Planaltina, Embrapa Cerrados 3p. (Circular Técnica, 81).

Grønvold, J., Henriksen, S.A., Larsen, M., et al., 1996. Biological control aspects of biological control —with special reference to arthropods, protozoans and helminths of domesticated animals. Vet. Parasitol. 64, 47-64.

Honer, M.R., Bianchin, I., Gomes, A., 1993.. Mosca-dos-chifres: histórico, biologia e controle. Campo Grande, Embrapa-CNPGC.

Inomoto, M.M., Machado, A.C.Z., Antedomenico, S.R., 2007. Host status of Brachiaria spp. and Panicum maximum to Pratylenchus brachyurus. Fitopatol. Bras. 32, 341-344.

Jose, S., 2009. Agroforestry for ecosystem services and environmental benefits: an overview. Agrofor. Syst. 76, 1-10.

Leme, T.M.S.P., Pires, M.F.A., Verneque, R.S., Alvim, M.J., Aroeira, L.J.M., 2005 Behavior of holstein $\times$ zebu crossbreed cows grazing Brachiaria decumbens in a silvipastoral system. Ciênc agrotec. 29, 668-675.

Martinez, J., Merino, S., 2011. Host-parasite interactions under extreme climatic conditions. Curr. Zool. 57, 390-405.

Oliveira, M.C.S., Nicodemo, M.L.F., Pezzopane, J.R.M., Gusmão, M.R., Chagas, A.C.S., Giglioti, R., Bilhassi, T.B., Santana, C.H., Gonçalves, T.C., Rabelo, M.D., Néo, T.A., 2016.. Gastrointestinal nematode infection in beef cattle raised in silvopastoral and conventional systems in São Paulo state, Brazil. Agrof. Sys. 1-13.

Statistical Analyses System - SAS, 2002. SAS/INSIGHT User's Guide, Version 9 1.3, Version to Windows. SAS Institute, CD-ROM, Cary.

Silva, G.S., Borges, W.L., de Freitas, R.S., et al., 2013. Projeto Integração Lavoura Pecuária Floresta (ILPF) do Polo Regional do Noroeste Paulista: Principais Resultados Parasitológicos e de Desempenho Animal. (Accessed September 23, 2016). http:// www.iac.sp.gov.br/publicacoes/publicacoes online/pdf/Documentos IAC 111.pdf.

Soca, M., Simón, L., Sánchez, S., Gómez, E., 2002. Dinámica parasitológica em bostas de bovinos bajo condiciones silvopastoriles. Agroforesteria em lãs Américas 9, 33-34.

Souza, L.F., Maurício, R.M., Gonçalves, L.C., Saliba, E.O.S., Moreira, G.S., 2007. Productivity and nutritional value of Brachiaria brizantha cv: Marandu in a silvopastoral system. Arq. Bras. Med. Vet. Zootec. 59, 1029-1037.

Tobin, P.C., Pitts, C.W., 1999.. Flotation method for extracting insects from poultry manure samples. J. Med. Entomol. 36, 121-123. 